Vol. 10(12), pp. 1633-1640, 23 June, 2015

DOI: $10.5897 /$ ERR2015.2282

Article Number: OE79E6753600

ISSN 1990-3839

Educational Research and Reviews

Copyright (C) 2015

Author(s) retain the copyright of this article

http://www.academicjournals.org/ERR

\title{
The mediation effect of school satisfaction in the relationship between teacher support, positive affect and life satisfaction in adolescents
}

\author{
Bülent Baki Telef $^{1^{*}}$, Gökmen Arslan ${ }^{2}$, Abdullah Mert $^{3}$ and Sezai Kalafat ${ }^{4}$ \\ ${ }^{1}$ Çanakkale Onsekiz Mart University/Turkey. \\ ${ }^{2}$ Süleyman Demirel University/Turkey. \\ ${ }^{3}$ Ministry of National Education/Turkey. \\ ${ }^{4}$ Bülent Ecevit University/Turkey.
}

Received 5 May, 2015; Accepted 10 June, 2015

\begin{abstract}
The aim of this study is to examine the relationships among teacher support, positive emotions, school satisfaction and life satisfaction in adolescences. The study had the participation of 344 adolescents from different socio-economic levels studying in the sixth, seventh and eighth grades of three public middle schools in the province of Chanakkale. The study population consisted of $173(50.3 \%)$ girls and $171(49.7 \%)$ boys. The data from the study were collected with the School Climate Inventory, Scale of Positive and Negative Experiences, Overall School Satisfaction Scale for Children, and Satisfaction with Life Scale. The results of structural equation modeling analysis showed that the good fit indexes of the model are at acceptable levels. Teacher support and positive emotions predict life satisfaction both directly and indirectly through school satisfaction. It was observed that school satisfaction is a mediating variable between teacher support and positive emotions with respect to life satisfaction. It can be said that teacher support and positive emotions are important factors in terms of school satisfaction and life satisfaction in adolescents.
\end{abstract}

Key words: Adolescence, positive emotions, teacher support, school satisfaction, life satisfaction.

\section{INTRODUCTION}

Life satisfaction is defined as a person's cognitive assessment of quality or positivity within overall or specific domains (family, school, environment, etc.) of life (Haranin et al., 2007). According to Suldo and Huebner (2004), life satisfaction may serve as a significant psychological strength for adolescents. The identification of factors affecting life satisfaction is important for the psychological development and adaptation of adolescents (Çivitci, 2009). Gilman and Huebner (2006) suggested that adolescents with high life satisfaction experience have fewer problems in the personal, interpersonal and academic domains. Adolescents with high life satisfaction are more likely to have positive beliefs regarding the management of negative emotions, better social

*Corresponding author. E-mail: bakitelef@gmail.com.

Authors agree that this article remain permanently open access under the terms of the Creative Commons Attribution License 4.0 International License 
performance and academic success (Antaramian et al., 2008).

School satisfaction is considered to be major aspect of overall life satisfaction (Verkuyten and Thijs, 2002; Karatzias et al., 2013). School satisfaction involves the subjective and cognitive assessment of perceived quality of school life (Baker et al., 2003). School satisfaction can facilitate the development of behaviors in adolescents that require responsibility by affecting not only doing good things but also active participation in the learning process within school (Elmore and Huebner, 2010). High school satisfaction is more likely to lead to the motivation for learning (Samdal et al., 1999). Adolescents who feel good about themselves and achieve satisfaction at school are less prone to behavioral problems (Engels et al., 2004; DeSantis-King et al., 2006).

\section{Teacher Support, School and Life Satisfaction}

Good relationships among teachers and students will not only encourage the efficient transfer of information but can also serve as a channel of emotional support for the students (Kim and Kim, 2013). Supportive and nurturing teacher behaviors, regardless of students' academic orientation or status, can provide the fundamental trust for learning and development in students (Jiang et al., 2013). Teacher support, as being a formative figure of students' achievements and developmental steps, helps students to recognize their capacity for learning and develop what they want. This support delivers cognitive information to students as learners, so they can use it to judge their own abilities (DeSantis King et al., 2006).

Social support of teachers, in the emotional and practical sense, has a significant impact on students' school satisfaction (Samdal et al., 1998). Review of the literature shows that teacher support has a positive relationship with school satisfaction (Casas et al., 2013; DeSantis King et al., 2009; Ferguson et al., 2010; Samdal et al., 1998; Ozdemir and Sezgin, 2011; Tian et al., 2013; Wentzel, 1998; Vieno et al., 2004; Zullig et al., 2011). Supportive, improvement-oriented teachers enhance the capacities of students concerning their school lives by allowing them to enjoy their learning experiences, encouraging them to strive to be successful and providing them with information. Nevertheless, indifferent or punitive teachers can create a negative environment in school. Therefore, teachers are an important piece of the puzzle, particularly in regard to their consideration of how students would achieve satisfaction in school (DeSantisKing et al., 2009). It is important to establish a school environment that supports and organizes the relationship between the teacher and the student, and where the students perceive school to be a safe place. The creation of such a school environment would improve students' educational experiences while boosting their health and well-being (Samdal et al., 1998). In the studies, a positive relationship between teacher support and the life satisfaction of adolescents was found (Danielsen, 2010; Suldo et al., 2009; Ferguson et al., 2010; Özdemir and Koruklu, 2013).

\section{Positive Emotions, School and Life Satisfaction}

Positive affects are among the emotional sub-dimensions of subjective well-being. Positive affects enable positive school functions to be increased by enhancing interpersonal interactions, coping with academic activities, flexibility and responsibility, school-related practices (Lewis et al., 2009). Positive affects protect adolescents from risky behaviors and dropping out of school (Telef, 2014a).

Positive relationships were found among positive affects and teacher-student relationships, control, attention, peer and family support in learning, future needs and goals, the obtainment of social support, problem-solving and self-confidence (Reschly et al., 2008).

Based on the studies, positive affects and school satisfaction were found to be positively correlated (Bordwine and Huebner, 2010; Huebner and McCullough, 2000; Karatzias et al., 2002; Lewis et al., 2009; Tian et al., 2013). In contrast to this situation, stressful school life (Baker, 1998; Vieno et al., 2004) and affective disorders (Jovanović and Jerković, 2011) reduce school satisfaction. Positive affects increase the likelihood that a person will feel much better in the present and the future (Fredrickson, 2004). Positive affects are the source of strong development and change, that they are predictors of a person's judgment on the life and skills possessed by people as means to achieve a better life (Cohn et al., 2009). It was found that adolescents who experience high positive affects have high life satisfaction (Garcia and Siddiqui, 2009; Rose, 2008; Froh et al., 2009; Telef, 2013; Veronese et al., 2012).

Consequently, studies reported in the literature support the conclusion that teacher support, positive affects, school satisfaction and life satisfaction are closely related as concepts. Therefore, in this study the mediation effect of school satisfaction in the relationship between teacher support and positive affects with respect to life satisfaction was examined through structural equation modeling. With reference to the studies reported in the literature, the following hypotheses based on the theoretical model were tested (Figure 1):

$\mathrm{H}_{1}$ : Teacher support has a direct effect on school satisfaction.

$\mathrm{H}_{2}$ : Positive affects have a direct effect on school satisfaction. 


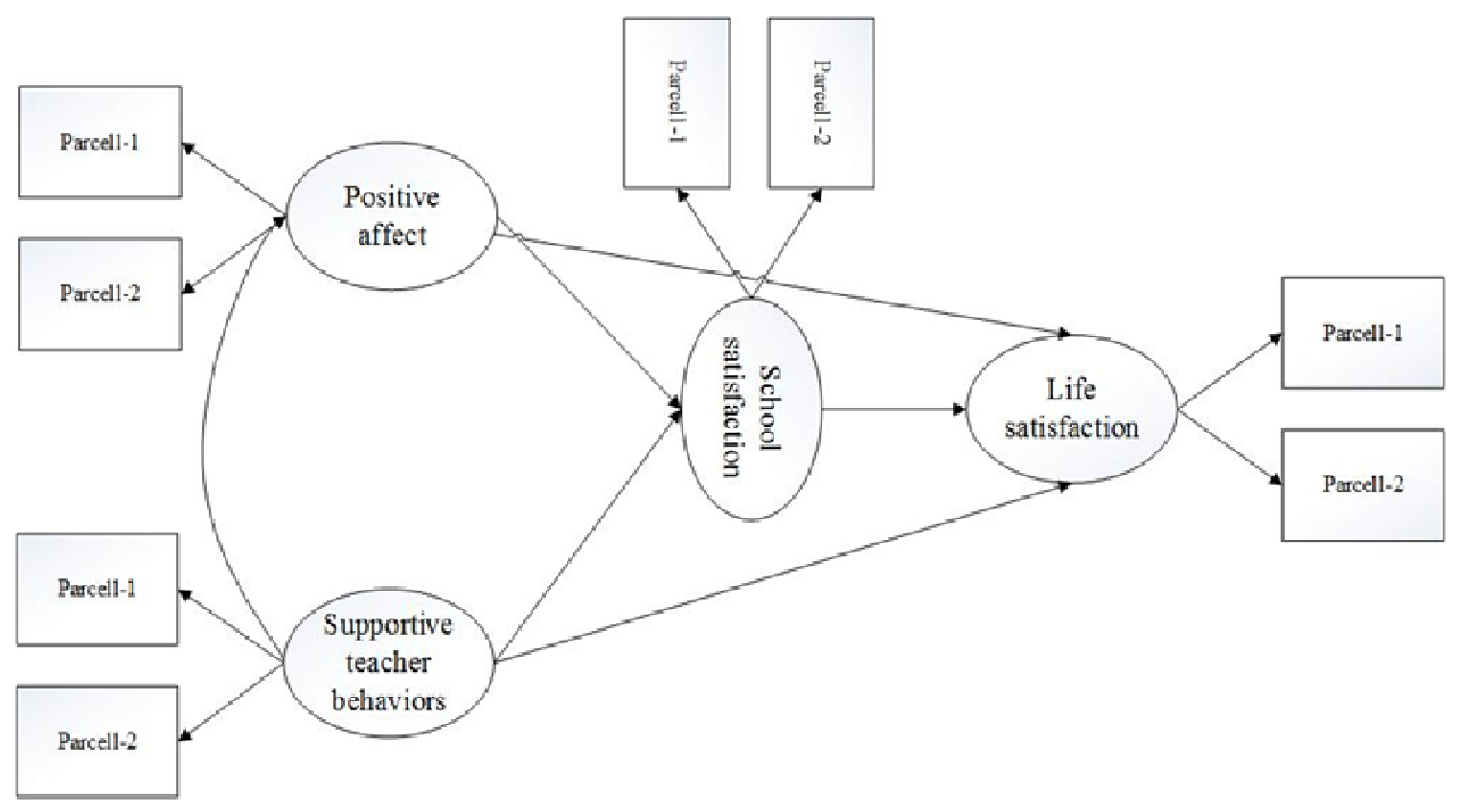

Figure 1. The hypothesized model.

$\mathrm{H}_{3}$ : School satisfaction has a direct effect on a student's life satisfaction.

$\mathrm{H}_{4}$ : Teacher support has a direct effect on a student's life satisfaction.

$\mathrm{H}_{5}$ : Positive affect has a direct effect on a student's life satisfaction.

$\mathrm{H}_{6}$ : Teacher support indirectly affects the student's life satisfaction through school satisfaction.

$\mathrm{H}_{7}$ : Positive affect indirectly affects the student's life satisfaction through school satisfaction.

\section{METHOD}

\section{Participants}

This research is based on the relational screening model. Relational screening model is a research model that aims at determining the existence and degree of the change between two and more variables (Karasar, 2005). Participants of the research were selected from the 6,7 and $8^{\text {th }}$ grades of three secondary schools located in the center of Çanakkale with the random sampling method. For the implementation, permissions were obtained from firstly the ethics committee of Çanakkale Onsekiz Mart University and then the Provincial Directorate of National Education. Parents were informed and their approvals were taken for the implementation through the school managers. Students were informed before the implementation and voluntary participation was remarked. Implementations of the scales were conducted in course hours and collectively. Students had 25-30 s to complete the survey. A total of 344 adolescents participated in the study.

Of the study population, 173 participants $(50.3 \%)$ were girls and $171(49.7 \%)$ were boys. Of those students, $74(21.5 \%)$ were in sixth grade, $209(60.8 \%)$ were in seventh grade and $61(17.7 \%)$ were in eighth grade. The participants ranged from 11 to 15 years of age. The mean age was 12.75 and the standard deviation was .87 .

\section{Measures \\ Satisfaction with life scale}

The Satisfaction with Life Scale, developed by Diener et al. (1985), was adapted into Turkish by Köker (1991). The scale consists of five items, and the items are evaluated between 1 (strongly disagree) and 7 (strongly agree). Scores received from the scale range from 5 to 35 . The low score obtained from the scale is considered to be an indication of low life satisfaction. The scale includes items like "I am pleased with my life". In the validity and reliability studies with adolescents conducted by Köker (1991), it was determined that the scale's test-retest reliability coefficient applied to the three-week interval was $r=.85$, and the item-test correlation was between $r=.71$ to $r=.80$. Cronbach's alpha internal consistency coefficient was found to be $(\alpha) .76$.

\section{Overall school satisfaction scale for children}

The Overall School Satisfaction Scale for Children was developed by Randolph and colleagues $(2009 ; 2010)$ to measure the comprehensive school satisfaction of primary-school students. It is a one-dimensional scale comprising six items. Each item in the scale is scored from 1 to 5 . The scale includes items like "I like going to school". A score between 6 and 30 is obtained from the scale. High scores indicate high school satisfaction and learning in school. The work of adapting the scale into Turkish was performed by Telef $(2014 \mathrm{~b})$ with 582 primary-school and middle-school students from the third through eighth grades. As a result of exploratory factor analysis, as was found in the original, the scale consisted of one factor, and the total variance was calculated to be 
$65 \%$. The factor loading of the scale items was calculated as .77 to .82. Goodness of fit values in the confirmatory factor analysis were found to be RMSEA $=0.06, \mathrm{SRMR}=0.01, \mathrm{GFI}=0.98, \mathrm{NFI}=0.99$, $\mathrm{RFI}=0.98, \mathrm{CFI}=0.99$ and $\mathrm{IFI}=0.99$. Cronbach's alpha internal consistency coefficient obtained from the reliability study of the scale was found to be .89 .

\section{School Climate Scale (SCS)}

The scale developed by Çalık and Kurt (2010) consists of 22 items prepared in the form of five-point Likert-type rating. The rating scale was formed from "never=1" to "always=5." The scale has three factors, including (1) supportive teacher behaviors, (2) achievement orientation, and (3) a safe learning environment and positive peer interaction. The subdimension of the scale, which constitutes the supportive teacher behaviors, consists of items such as "our teachers make the classroom environment enjoyable". According to the results of the original validity and reliability studies of the scale, the factor-loading values of the items in the three-factor structure ranged from .45 to .85 , and the total variance was $45 \%$. The internal consistency coefficients calculated to determine the reliability level of the scores obtained from the factors ranged from .77 to .85 . In this study, the supportive teacher behaviors subdimension of the scale was used.

\section{Scale of positive and negative experiences}

The Scale of Positive and Negative Experiences is a short scale that was developed by Diener et al. (2010) in order to measure positive affects, negative affects and well-being. The Turkish adaptation of the scale was performed by Telef $(2011,2015 ; 2013)$. As a result of confirmatory factor analysis, the goodness of fit indexes of the scale were found to be RMSEA $=0.04$, SRMR $=$ $0.03, \mathrm{GFI}=0.96, \mathrm{NFI}=0.97, \mathrm{RFI}=0.96, \mathrm{CFI}=0.99$ and $\mathrm{IFI}=0.99$. Cronbach's alpha coefficient obtained from the reliability study of the scale was found to be .84 for positive experience dimension and .75 for negative experience dimension. Each item in the Scale of Positive and Negative Experiences is scored in the range from 1 to 5 and expressed in the form of 1 (very rarely or never) to 5 (very often or always). Given the fact that the scale measures the independent or two different types of feelings, they are scored separately. The sum of positive and negative scores ranges from 6 to 30 . Items that measure the positive experiences include feelings like "happy and pleased". In the study, the positive experience subscale was used to measure the positive emotions.

\section{Demographic information}

The Personal Information Form was prepared by the researchers to gather demographic information regarding the students. Personal information of students such as gender, grade and age is found in the form.

\section{Analyses}

Analysis was organized in two steps. In first step, descriptive statistics and Pearson correlation confidents were examined by using SPSS 22. Multivariate assumptions were also checked including normality, missing values, and outlier values. In second step, structural equation modeling was used to measure direct and indirect relationship between variables by using AMOS 22. $\chi^{2}$ (ChiSquared statistics), $\chi 2 / d f$ (degree of freedom), RMSEA (Root Mean Square Error of Approximation), SRMR (Standardized Root Mean Square), GFI (Goodness of Fit Index), CFI (Comparative Fit Index), NFI (Normed Fit Index), and RFI (Relative Fit Index) were used to assess the model fit. For CFI, GFI, NFI, RFI, .90 and higher value show acceptable fit, and $\chi 2 / \mathrm{df}<.03$ is accepted a good fit. Finally less than .05 of RMSEA and SRMR indicate a good fit (Kline, 2011; Şimşek, 2007).

\section{RESULTS}

Before the structural equation analysis, we examined descriptive statistics and Pearson correlation for relationships between variables. Result of descriptive statistics and correlation are presented in Table 1.

As seen in Table 1, results indicated that life satisfaction positively correlated with supportive teacher behaviors, school satisfaction, and positive affect in adolescents. For examining the mediation role of school satisfaction in relationship between supportive teacher behaviors-life satisfaction and positive affect-life satisfaction, structural equation modeling (SEM) was used. Latent constructs were defined to using parcel method, and two parcels were determined for each latent variable.

In structural equation, standardized regression coefficients indicated that positive affect $(\beta=.21, p<.05)$ and supportive teacher behaviors $(\beta=.32, \quad p<.001)$ directly predicted school satisfaction. School satisfaction predicted life satisfaction $(\beta=.25, p<.001)$ significantly. Analysis results also showed that positive affect $(\beta=.19$, $p<.05)$ and supportive teacher behaviors $(\beta=.28$, $p<.001)$ indirectly predicted life satisfaction via school satisfaction. In other words, school satisfaction partially mediated in relationship between supportive teacher behaviors - life satisfaction and positive affect- life satisfaction. Positive affect and supportive teacher behaviors accounted for $24 \%$ of variance in school satisfaction, and positive affect supportive teacher behaviors and school satisfaction accounted for $35 \%$ of variance in life satisfaction in structural model (Figure 2).

\section{DISCUSSION}

This study tested the mediation role of school satisfaction in the relationships between supportive teacher behaviors and positive affects with respect to life satisfaction in adolescents. The results of structural equation modeling showed that supportive teacher behaviors and positive affects predict life satisfaction both directly and indirectly through school satisfaction.

Supportive teacher behavior was observed to be an important predictor of school satisfaction. This finding is consistent with the results in the literature, which indicate 
Table 1. Descriptive statistics and correlation values for variables.

\begin{tabular}{lllllllllllll}
\hline & $\mathbf{1}$ & $\mathbf{2}$ & $\mathbf{3}$ & $\mathbf{4}$ & $\mathbf{5}$ & $\mathbf{6}$ & $\mathbf{7}$ & $\mathbf{8}$ & $\mathbf{9}$ & $\mathbf{1 0}$ & $\mathbf{1 1}$ & $\mathbf{1 2}$ \\
\hline PE & 1 & & & & & & & & & & & \\
SS & $.347^{* *}$ & 1 & & & & & & & & & & \\
LS & $.396^{* *}$ & $.374^{* *}$ & 1 & & & & & & & & & \\
STB & $.510^{* *}$ & $.386^{* *}$ & $.418^{* *}$ & 1 & & & & & & & & \\
STB1 & $.513^{* *}$ & $.350^{* *}$ & $.391^{* *}$ & $.892^{* *}$ & 1 & & & & & & & \\
STB2 & $.417^{* *}$ & $.350^{* *}$ & $.366^{* *}$ & $.917^{* *}$ & $.636^{* *}$ & 1 & & & & & & \\
PE1 & $.923^{* *}$ & $.347^{* *}$ & $.361^{* *}$ & $.460^{* *}$ & $.475^{* *}$ & $.365^{* *}$ & 1 & & & & & \\
PE2 & $.937^{* *}$ & $.301^{* *}$ & $.375^{* *}$ & $.488^{* *}$ & $.478^{* *}$ & $.409^{* *}$ & $.730^{* *}$ & 1 & & & & \\
SS1 & $.360^{* *}$ & $.934^{* *}$ & $.374^{* *}$ & $.335^{* *}$ & $.289^{* *}$ & $.316^{* *}$ & $.351^{* *}$ & $.320^{* *}$ & 1 & & & \\
SS2 & $.284^{* *}$ & $.927^{* *}$ & $.321^{* *}$ & $.385^{* *}$ & $.364^{* *}$ & $.335^{* *}$ & $.294^{* *}$ & $.238^{* *}$ & $.731^{* *}$ & 1 & & \\
LS1 & $.331^{* *}$ & $.372^{* *}$ & $.861^{* *}$ & $.363^{* *}$ & $.357^{* *}$ & $.304^{* *}$ & $.295^{* *}$ & $.319^{* *}$ & $.350^{* *}$ & $.341^{* *}$ & 1 & \\
LS2 & $.385^{* *}$ & $.331^{* *}$ & $.959^{* *}$ & $.398^{* *}$ & $.364^{* *}$ & $.357^{* *}$ & $.355^{* *}$ & $.361^{* *}$ & $.343^{* *}$ & $.272^{* *}$ & $.681^{* *}$ & 1 \\
M & 23.47 & 23.80 & 28.36 & 28.20 & 14.61 & 13.59 & 11.46 & 12.00 & 11.70 & 12.10 & 11.89 & 16.46 \\
SD & 4.826 & 5.307 & 6.277 & 7.052 & 3.654 & 4.139 & 2.470 & 2.718 & 2.920 & 2.784 & 2.434 & 4.360 \\
\hline
\end{tabular}

Note: $\mathrm{N}=344,{ }^{* *} \mathrm{p}<.001$, OY positive affect; DOD supportive teacher behaviors; OD school satisfaction; YD life satisfaction, OD1, OD2, OY1, OY2, DOD1, DOD2, YD1, YD2 define parcels for latent constructs.

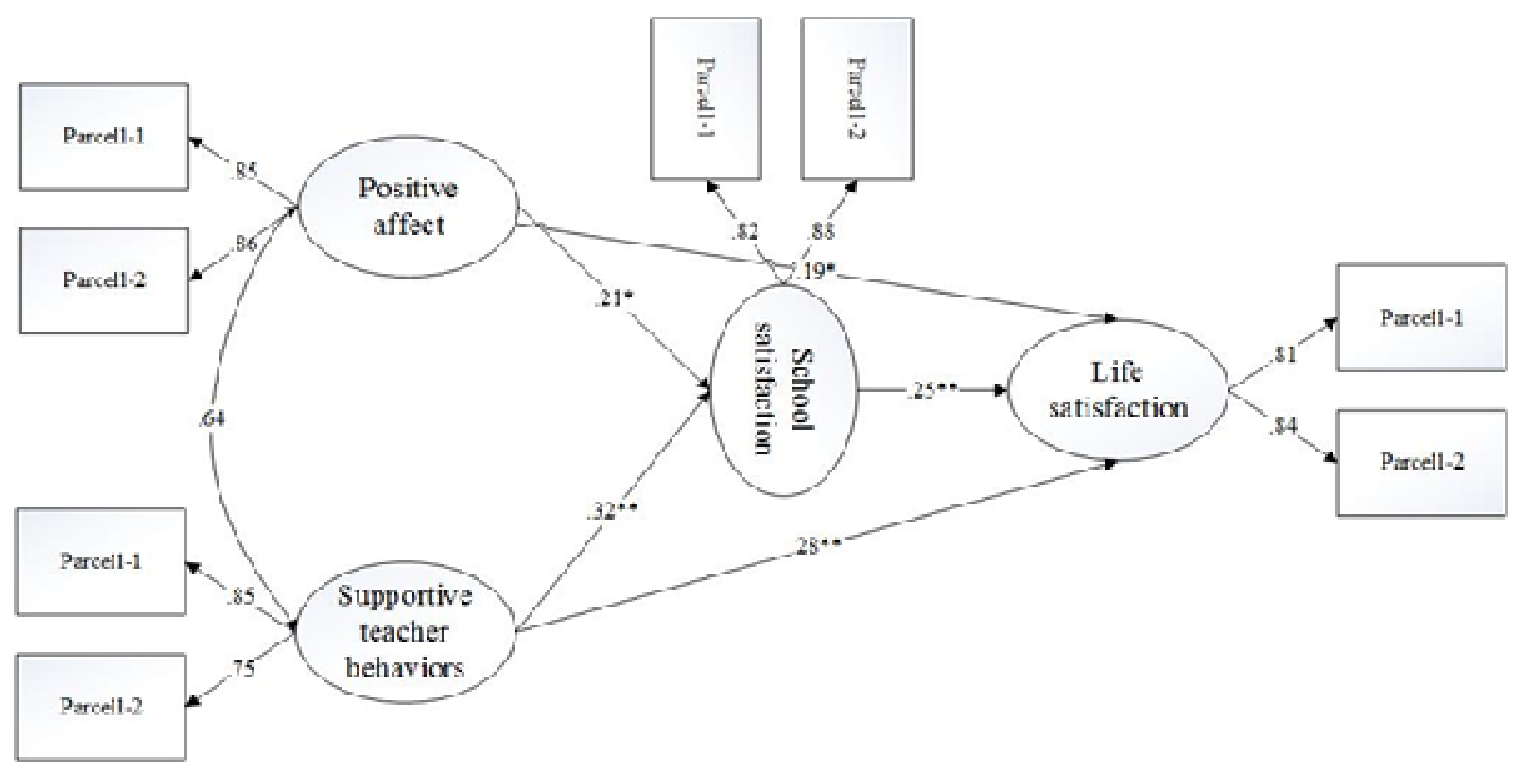

Figure 2. Structural model regarding standardized estimates. Note: $\mathrm{N}=344,{ }^{*} p<.05,{ }^{* *} p<.001$.

that support received from teachers is relevant to the student's school satisfaction (Casas et al., 2013; DeSantis King et al., 2009; Ferguson, Kasser and Jahng, 2010; DeSantis-King et al., 2006; Samdal et al., 1998; Özdemir and Sezgin, 2011; Tian et al., 2013; Vieno et al., 2004; Wentzel, 1998; Zullig, Huebner and Patton, 2011). Good relationships between teachers and students contribute to the school satisfaction of students in a unique way (Jiang, Huebner and Siddall, 2013; Kim and
Kim, 2013). As support from teacher increases, so does school satisfaction (DeSantis-King et al., 2006).

According to Suldo et al. (2004), supporting relationships lead to a positive school climate that enables students to evaluate their school experiences positively. The support received from one or multiple teachers increases the feeling of connection to school in adolescents. Therefore, this situation causes them to assess their school satisfaction as being positive and to 
show fewer behavioral problems (DeSantis-King et al., 2006).

Supportive teacher behavior can significantly predict the life satisfaction of adolescents. Numerous studies have asserted that support from the teacher is an important factor in the adolescent's life satisfaction (Danielsen, 2010; Ferguson et al., 2010; Suldo et al., 2009; Özdemir and Koruklu, 2013; Vieno et al., 2004). The meta-analysis study conducted by Chu et al. (2010) found that support obtained from teachers and school personnel is associated with the well-being of adolescents. According to Suldo et al. (2009), emotional and mediational support from teachers is important in the well-being of students. Teacher support serves as a form of protection against the vulnerability that increases in the situations where well-being decreases in adolescents (Reddy et al., 2003). Support from the teacher may help the student cope with the demands of school and help him or her avoid problems such as life dissatisfaction and subjective health complaints (Ravens-Sieberer et al., 2009). The role of the teacher and learning environment are critically important in terms of improving well-being in school (Løhre et al., 2010). According to Samdal et al. (1998), it is fundamental to establish a school environment that supports and organizes the relationship between teachers and students, and where the students perceive the environment to be safe. The creation of such a school environment will improve students' educational experiences and enhance their health and well-being. According to Döş (2013), in a happy school environment the teachers are close to students, listen to their problems, treat them warmly and help them to solve their problems.

Positive affects have been recognized as significant predictors of school satisfaction. The positive relationship between positive affects and school satisfaction is supported by previous research results (Bordwine and Huebner, 2010; Huebner and McCullough, 2000; Karatzias et al., 2002; Lewis et al., 2009; Tian et al., 2013). According to Lewis et al. (2009), positive affects significantly aid the understanding of students' compatibility-oriented school behaviors. Positive affects were found to be positively associated with adolescents' life satisfaction. This finding is consistent with research results indicating that, as positive affects increase life satisfaction also increases (Froh et al., 2009; Rose, 2008; Telef, 2013; Veronese et al., 2012). It was pointed out that positive affects and experiences can be used as tools for the development of life satisfaction in adolescents (Rose, 2008). Positive emotions, as compared to negative emotions, play a key role in a person's overall life satisfaction by enabling the individual to enjoy more (Veronese et al., 2012). As for adolescents who often have been exposed to negative experiences, they gradually lose their perception of control over their lives, and this situation leads to a decrease in life satisfaction (Ash and Huebner, 2001).

As is the case with previous studies (DeSantis et al., 2009), it was observed that school satisfaction is an intermediary variable between supportive teacher behaviors and life satisfaction. This is consistent with the previous literature reporting that that high school satisfaction is associated with high life satisfaction (Ash and Huebner, 1998; Huebner and Gilman, 2006; McGrath et al., 2009; Park and Huebner, 2005; Telef, 2014b). Supportive teacher behaviors and positive affects encourage the increase of school satisfaction in adolescents. It can be stated that this situation conduces them to enjoy life more. Intervention strategies intended to deal with stress or reduce it, and to improve personal relationships in school, can prevent diseases while promoting general well-being and health (Natvig et al., 2003). Efforts which will be made by the educators to develop the teacher-student relationships, increase the teacher support and create a positive school climate can enable the students to be satisfied with both the school and their lives.

There are some limitations in this study. First, the research data was collected from students at just three middle schools in the province of Çanakkale. The research can be repeated with samples from larger and different age groups to increase the generalizability of the findings. In the research, factors such as gender and socio-economic status weren't included in the model. In further researches, demographic variables can be added to the model and relationships can be tested. Research data were collected on the basis of self-report method. In future studies, mixed studies can be conducted using both quantitative and qualitative methods. The findings obtained as a result of this research may contribute to the comprehension of the adolescents' well-beings.

\section{Conflict of Interests}

The authors have not declared any conflict of interests.

\section{REFERENCES}

Antaramian SP, Huebner ES, Valois RF (2008). Adolescent life satisfaction. Appl. Psychol. Int. Rev. 57:112-126.

Ash C, Huebner ES (1998). Life satisfaction reports of gifted middleschool children. School Psychol Q. 13:310-321.

Baker JA (1998). The social context of school satisfaction among urban, low-income, African-American students. School Psychol Quart. 13:25- 44 .

Baker JA, Dilly LJ, Aupperlee JL, Patil SA (2003). The developmental context of school satisfaction: Schools as psychologically healthy environments. School Psychol Q. 18(2):206-221.

Bordwine VC, Huebner ES (2010). The role of coping in mediating the relationship between positive affect and school satisfaction in adolescents. Child Ind. Res. 3(3):349-366. 
Casas F, Bello A, González M, Aligué M (2013). Children's subjective well-being measured using a composite index: What impacts Spanish first-year secondary education students' subjective well-being? Child Ind. Res. 6(3):1-28.

Chu PS, Saucier DA, Hafner E (2010). Meta-analysis of the relationships between social support and well-being in children and adolescents. J. Soc. Clin. Psychol. 29:624-645. http://doi.org/cwdf7q

Cohn MA, Fredrickson BL, Brown SL, Mikels JA, Conway AM (2009). Happiness unpacked: Positive emotions increase life satisfaction by building resilience. Emotion. 9:361-368. doi:10.1037/a0015952.

Çalık T, Kurt T (2010). Okul Iklimi Ölçeği'nin geliştirilmesi. Eğitim ve Bilim. 35:167-180.

Çivitci A (2009). İlköğretim öğrencilerinde yaşam doyumu: Bazı kişisel ve ailesel özelliklerin rolü. Uludağ Üniversitesi Eğitim Fakültesi Dergisi 12(1):29-52.

Danielsen AG (2010). Supportive and motivating environments in school: Main factors to make well-being and learning a reality. Norsk Epidemiologi. 20(1):33-39.

DeSantis King AL, Huebner S, Suldo SM, Valois RF (2006). An ecological view of school satisfaction in adolescence: Linkages between social support and behavior problems. Appl. Res. Q. Life. 1:279-295. DOI 10.1007/s11482-007-9021-7.

DeSantis King AL, Samdal O, Hetland J, Wold B (2009). School-related social support and students' perceived life satisfaction. J. Educ. Res. 102:303-318.

Diener E, Emmons RA, Larsen RJ, Griffin S (1985). The satisfaction with life scale. J. Pers. Assess. 49:71-75.

Diener E, Wirtz D, Biswas-Diener R, Tov W, Kim-Prieto C, Choi D, et al (2010). New well-being measures: short scales to assess flourishing and positive and negative feelings. Soc. Indic. Res. 97:143-156.

Döş İ (2013). Mutlu okul. Eğitim ve Bilim. 38(170):266-280.

Elmore GM, Huebner ES (2010). Adolescents' satisfaction with school experiences: Relationships with demographics, attachment relationships, and school engagement. Psychol. Sch. 47(6):525-537.

Engels N, Aelterman A, Petegem KV, Schepens A (2004). Factors which influence the well-being of pupils in Flemish secondary schools. Educ. Stud. 30(2):127-143.

Ferguson YL, Kasser T, Jahng S (2010). Differences in life satisfaction and school satisfaction among adolescents from three nations: The role of perceived autonomy support. J. Res. Adolesc. 21(3):649 661.

Fredrickson BL (2004). Gratitude, like other positive emotions, broadens and builds. In: Emmons, R. A. \& M. E. McCullough (Eds.) The Psychology of Gratitude. New York: Oxford University Press. pp.145166.

Froh JJ, Yurkewicz C, Todd BK (2009). Gratitude and subjective wellbeing in early adolescence: Examining gender differences. J. Adolesc. 32(3):633-650.

Garcia D, Siddiqui A (2009). Adolescents' psychological well-being and memory for life events: Influences on life satisfaction with respect to temperamental dispositions. J. Happiness Stud. 10:387-503.

Gilman R, Huebner ES (2006). Characteristics of adolescents who report very high life satisfaction. J. Youth Adolesc. 35(3):293-301. doi:10.1007/s10964-006-9036-7.

Haranin E, Huebner ES, Suldo SM (2007). Predictive and incremental validity of global and domain-based adolescent life satisfaction reports. J. Psycho. educ. Assess. 25:127-138.

Huebner ES, McCullough G (2000). Correlates of school satisfaction among adolescents. J. Educ. Res. 93(5):331-335.

Huebner ES, Gilman R (2006). Students who like and dislike school. Appl. Res. Qual. Life 1:139-150.

Jiang X, Huebner ES, Siddall J (2013). Short-term longitudinal study of differential sources of school-related social support and adolescents school satisfaction. Soc. Indic Res. 114:1073-1086.

Jovanović V, Jerković I (2011). School satisfaction among secondary school students- relations with school achievement and mental health indicators. Psihologija 44(3):211-224.

Karasar N (2005). Bilimsel Araştırma Yöntemi. Ankara: Nobel Yayın
Dağıtım.

Karatzias A, Power KG, Flemming J, Lennan F, Swanson V (2002). The role of demographics, personality variables and school stress on predicting school satisfaction/dissatisfaction: Review of the literature and research findings. Educational Psychology: Int. J. Exp. Educ. Psychol. 22(1):33-50.

Kim DH, Kim JH (2013). Social relations and school life satisfaction in South Korea. Soc. Indic. Res. 112:105-127. DOI 10.1007/s11205012-0042-8.

Kline RB (2011). Principles and practices of structural equation modeling. New York: The Guil-ford Press.

Köker S (1991). Normal ve sorunlu ergenlerin yaşam doyumu düzeylerinin karşıllaştırılması. Yayınlan-mamış Yüksek Lisans Tezi, Ankara, Ankara Üniversitesi, Sosyal Bilimler Enstitüsü. Ankara.

Lewis AD, Huebner ES, Reschly AL, Valois RF (2009). The incremental validity of positive emotions in predicting school functioning. J. Psychoeduc. Assess. 27:397-408.

Løhre A, Lydersen S, Vatten LJ (2010). School wellbeing among children in grades 1-10. BMC Public Health 10:526.

McGrath B, Brennan MA, Dolan P, Barnett R (2009). Adolescent wellbeing and supporting contexts: a comparison of rural adolescents in Ireland and Florida. J. Commun. Appl. Soc. 19:299-320.

Natvig GK, Albrektsen G, Qvarnstrom U (2003). Associations between psychosocial factors and happiness among school adolescents. Int. J. Nurs. Pract. 9:166 -175.

Özdemir S, Sezgin F (2011). İlköğretim okulu öğrencilerinin yönetici ve öğretmen desteği, algılanan şiddet ve okul memnuniyetine ilişkin görüşleri. İnönü Üniversitesi Eğitim Fakültesi Dergisi 12:181-199.

Özdemir Y, Koruklu N (2013). Parental attachment, school attachment and life satisfaction in early adolescence. Elem. Educ. Online. 12(3):836-848.

Park N, Huebner ES (2005). A cross-cultural study of the levels and correlates of life satisfaction among adolescents. J. Cross Cult. Psychol. 36:444-456.

Randolph JJ, Kangas M, Ruokamo H (2009). The preliminary development of the children's overall satisfaction with schooling scale. Child Ind. Res. 2(1):79-93.

Randolph JJ, Kangas M, Ruokamo H (2010). Predictors of Dutch and Finnish students' satisfaction with schooling. J. Happiness Stud. 11(2):193-204.

Ravens-Sieberer U, Freeman J, Kokonyei G, Thomas CA, Erhart M (2009). School as a determinant for health outcomes - a structural equation model analysis. Health Educ. 109( 4):342-356.

Reddy R, Rhodes JE, Mulhall P (2003). The influence of teacher support on student adjustment in the middle school years: A latent growth curve study. Dev. Psychopathol. 15(01):119-138.

Reschly AL, Huebner ES, Appleton JJ, Antaramian S (2008). Engagement as flourishing: The contribution of positive emotions and coping to adolescents' engagement at school and with learning. Psychol. Sch. 45(5):419-431.

Rose L(2008). Positive affect and life satisfaction in Australian adolescents. Thesis Doctorate of Psychology, University of Southern Queensland.

Samdal O, Nutbeam B, Wold B, Kannas L (1998). Achieving health and educational goals through schools-a study of the importance of school climate and the students' satisfaction with school. Health Educ. Res. 13(3):383-397.

Samdal O, Wold B, Bronis M (1999). Relationship between students' perceptions of school environment, their satisfaction with school and perceived academic achievement: An international study. Sch. Eff. Sch. Improv. 10(3):296-320.

Suldo SH, Huebner ES (2004). Does life satisfaction moderate the effects of stressful life events on psychopathological behavior during adolescence? School Psychol. Quart. 19(2):93-105

Suldo SM, Friedrich AA, White T, Farmer J, Minch D, Michalowski J (2009). Teacher support and adolescents' subjective well-being: A mixed-methods investigation. School Psychol. Rev. 38(1):67- 85.

Şimşek ÖF (2007). Yapısal eşitlik modellemesine giriş: Temel ilkeler ve 
Lisrel uygulamaları. Ankara: Ekinoks Yayınevi.

Telef BB (2011). Adaptation of positive and negative experiences scale to Turkish; validity and reliability study 11 . The paper presented the Psychological Counseling and Guidance Congress. Izmir.

Telef BB (2013). The scale of positive and negative experience: A validity and reliability study for adolescents. Anadolu Psikiyatri Derg. 14:62-68.

Telef BB (2014a). Ergenlerde olumlu ve olumsuz duygular ile riskli davranışlar arasındaki ilişkinin incelenmesi. Kastamonu Eğitim Dergisi 22(2):591-604.

Telef BB (2014b). Çocuklar için Kapsamlı Okul Doyumu Ölçeği'nin Türkçeye uyarlama çalışması. Eğitimde Kuram ve Uygulama. 10(2):1-13.

Telef BB (2015). The positive and negative experience scale adaptation for Turkish university students. Euro. Scientific J. 11(14):49-59.

Tian I, Liu B, Huang S, Huebner ES (2013). Perceived social support and school well-being among Chinese early and middle adolescents: The mediational role of self-esteem. Soc Indic Res. 113(3):991-1008.

Verkuyten M, Thijs J (2002). School satisfaction of elementary school children: The role of performance, peer relations, ethnicity, and gender. Soc. Indic. Res. 59(2):203-228.

Veronese G, Castiglioni M, Barola G, Said M (2012). Living in the shadow of occupation: Life satisfaction and positive emotion as protective factors in a group of Palestinian school children. Child Youth Serv. Rev. 34:225-233.
Vieno A, Santinello M, Galbiati E, Mirandola M (2004). Running head: School setting school climate and well being in early adolescence: A comprehensive model. Euro. J. School Psychol. 2(1-2):219-238.

Wentzel K (1998). Social relationships and motivation in middle school: The role of parents, teachers, and peers. J. Educ. Psychol. 90(2):202-29.

Zullig KJ, Huebner ES, Patton JM (2011). Relationships among school climate domains and school satisfaction. Psychol. Schools. 48(2):133-145. 